\title{
Assessment of genetic diversity among Iranian Aegilops triuncialis accessions using ISSR, SCoT, and CBDP markers
}

\author{
Lavin Khodaee ${ }^{1}$, Reza Azizinezhad ${ }^{1 *}$, Ali Reza Etminan ${ }^{2}$ and Mahmoud Khosroshahi ${ }^{1}$
}

\begin{abstract}
Background: Crop wild relatives (CWRs) are commonly used as a suitable genetic reservoir for plant breeding. They can be used for enhancing the tolerance of plant varieties to biotic and abiotic stresses. Studying the genetic diversity of related wheat species in Iran could be useful to improve different traits of bread wheat, since the country is one of the major centers of genetic diversity and distribution of Aegilops species. Therefore, the aim of the present study was to determine the relationship among 48 Aegilops triuncialis accessions using three DNA marker systems, including start codon targeted (SCOT), CAAT box-derived polymorphism (CBDP), and inter-simple sequence repeat (ISSR) markers.
\end{abstract}

Results: A total of 359 amplified DNA fragments were generated using 13 CBDP, 14 SCOT, and 16 ISSR primers that produced 96, 147, and 152 bands, respectively. The discriminating power of the three markers was assessed using polymorphism information content (PIC), marker index (MI), and resolving power (Rp). The mean values of PIC for ISSR, SCOT, and CBDP markers were $0.3,0.26$, and 0.34 , respectively, indicating the efficiency of the three markers in detecting polymorphism among the studied accessions. ISSR markers had the highest values of Ml, Rp, and polymorphism percentage as compared to SCOT and CBDP markers. Based on the Shannon index and heterozygosity values, genetic diversity in the Alborz population was more than in other populations. The accessions were classified into six, five, and five groups based on ISSR, SCOT, and CBDP using the UPGMA method. According to the results of cluster and PCoA analyses, the variation patterns corresponded with the geographical distribution of the Ae. triuncialis accessions.

Conclusions: The three markers provided a comprehensive pattern of the genetic diversity among the Iranian Ae. triuncialis accessions. This information could allow for a future insight into wheat breeding programs.

Keywords: Ae. Triuncialis, Genetic diversity, Polymorphism, Wild wheat, Iran

\section{Background}

Crop wild relatives (CWRs) are a useful reservoir of beneficial genes and alleles that can be used for improving and adjusting varieties that are better suited and resistant to biotic and abiotic stress [1,2]. Due to global limitations on further land and water resources, plant breeders try to develop new plant varieties using CWRs.

\footnotetext{
* Correspondence: rezaazizinezhada@gmail.com

'Department of Biotechnology and Plant Breeding, Islamic Azad University Science and Research Branch, Tehran, Iran

Full list of author information is available at the end of the article
}

However, many CWRs are not adequately collected and are not currently conserved in gene banks across the world [3]. Wild relatives of common wheat (Triticum aestivum L.) are progenitors of precious genetic materials that can assist in breeding programs of wheat [4]. Interspecific crosses between wheat and its close wild relatives such as Aegilops species are useful for introducing desirable traits that can contribute to improvements in the germplasm of bread wheat $[5,6]$. Iran is one of the major centers of genetic diversity and distribution of related wheat species [7]. While many biotic and abiotic

\section{Springer Open}

(- The Author(s). 2021 Open Access This article is licensed under a Creative Commons Attribution 4.0 International License, which permits use, sharing, adaptation, distribution and reproduction in any medium or format, as long as you give appropriate credit to the original author(s) and the source, provide a link to the Creative Commons licence, and indicate if changes were made. The images or other third party material in this article are included in the article's Creative Commons licence, unless indicated otherwise in a credit line to the material. If material is not included in the article's Creative Commons licence and your intended use is not permitted by statutory regulation or exceeds the permitted use, you will need to obtain permission directly from the copyright holder. To view a copy of this licence, visit http://creativecommons.org/licenses/by/4.0/. 
stresses affect the quality and quantity of crops in Iran $[8,9]$, drought stress is one of the major environmental constraints that threaten plant survival, growth, and final yield. The Aegilops genus from the Poaceae family consists of 22 species which are native to Eurasia and North Africa. In fact, Ae. triuncialis is an allotetraploid with a UUCC genomic formula $(2 n=28)$ and with a basic chromosome number $(x=n=7)$, whereas bread wheat is an allohexaploid. The $\mathrm{U}$ genome played a major role in the evolution of domestic wheat [10].

The plant is resistant to various stresses such as drought and high salinity. It can be a suitable candidate to enable crosses with bread wheat so as to obtain new lines with high levels of drought stress tolerance [11]. Therefore, studying genetic diversity among the accessions of Ae. triuncialis could be useful for improving different traits in bread wheat.

Molecular techniques have added a new dimension to scientific research and have offered powerful pathways to identify and manipulate various genes [12]. Recently, molecular markers have played a major role in estimating diversity and evolutionary relationships. They can exclusively be effective for quantifying genetic diversity within plant species. They can be used for identifying and recognizing closely related genotypes [13]. In the past few years, many new gene-related target marker techniques have emerged. Two of these techniques are CBDP and SCoT [14]. SCoT markers are a new type of DNA markers that use single 18-mer primers based on short conserved regions that are close to the start codon ATG [15].

CBDP markers enable the CAAT box region of the plant gene promoters by using a single primer in PCR, similar to RAPD [16]. These two new markers display a higher reproducibility and can generate more information related to biological traits compared with random DNA markers [16]. Furthermore, the markers are novel, accessible, cost effective, and, generally, there is no requirement of prior sequence information of the genome. These markers represent a high level of polymorphism and efficiency. They are successfully utilized in different plant species such as Cicer species [17], bread wheat [18], date palm [18], and walnut [19]. ISSR markers are one of the most efficient marker systems because of their capacity to reveal several informative bands from a single amplification [20]. The marker has a high polymorphic degree among closely related varieties, along with high levels of repeatability and reliability which are efficiently used for assessing genetic variation in different crops such as Achillea species [21, 22], melon [23], Zingiber officinale [24], and cowpea [25]. Shortages in water resources are expected sooner or later in many parts of the world due to climate change and overpopulation [26].
Crosses between wheat and its close wild relatives such as Ae. triuncialis can be useful to obtain new drought-resistant varieties. Therefore, the present study was performed to evaluate the genetic diversity and relationships among Ae. triuncialis genotypes collected from different regions of Iran. The evaluations of genetic diversity and genetic relationships were based on SCoT, CBDP, and ISSR markers.

\section{Methods}

Plant materials and DNA extraction

Forty-eight accessions of Ae. triuncialis were collected from different geographical regions of Iran. Information on coordinate and habitat characteristics of the sampling locations are presented in Table 1.

The genomic DNAs were isolated from the young leaves of 2-week-old seedlings and were sampled from all genotypes based on the CTAB method [27]. The quality and quantity of the extracted DNAs were determined by both spectrophotometry and agarose gel electrophoresis.

\section{ISSR-PCR analysis}

A set of 16 ISSR primers were used for amplifying the genomic DNA of the accessions (Table 2). The PCR reactions were performed in a $20 \mu \mathrm{l}$ volume containing $10 \mu \mathrm{l}$ master mix 2X PCR (ready-to-use PCR master mix 2X; Ampliqon), $6 \mu$ l double distilled water, $2 \mu$ template DNA from each samples, and $1 \mu \mathrm{l}$ of each forward and reverse primers $(10 \mathrm{pmol} / \mu \mathrm{l})$. The amplifications were carried out at $94{ }^{\circ} \mathrm{C}$ for $4 \mathrm{~min}$, followed by 35 cycles of denaturation at $94{ }^{\circ} \mathrm{C}$ for $30 \mathrm{~s}$, primer annealing at 49.2 $54.8^{\circ} \mathrm{C}$ for $45 \mathrm{~s}$ and primer elongation at $72{ }^{\circ} \mathrm{C}$ for $2 \mathrm{~min}$, with a final extension at $72{ }^{\circ} \mathrm{C}$ for $7 \mathrm{~min}$ using a Bio-Rad (T100) thermal cycler. The DNA was diluted to a concentration of $50 \mathrm{ng} / \mu \mathrm{l}$ to be used in the assay.

\section{SCOT-PCR and CBDP-PCR analyses}

Fourteen SCoT primers and thirteen CBDP primers were selected to study genetic diversity among the accessions. The PCR reactions for SCoT markers were programmed by adhering to the following procedure: after initial denaturation of DNA at $94{ }^{\circ} \mathrm{C}$ for $5 \mathrm{~min}, 35$ cycles of DNA denaturation at $94{ }^{\circ} \mathrm{C}$ occurred for $30 \mathrm{~s}$, primer annealing occurred at $53.7-60.5^{\circ} \mathrm{C}$ for $45 \mathrm{~s}$ and at $72{ }^{\circ} \mathrm{C}$ for $2 \mathrm{~min}$, before a final extension at $72^{\circ} \mathrm{C}$ for $7 \mathrm{~min}$. The PCR condition for CBDP markers was set as follows: $5 \mathrm{~min}$ of an initial denaturing at $94^{\circ} \mathrm{C}, 30$ cycles of denaturing at $94^{\circ} \mathrm{C}$ for $30 \mathrm{~s}$, primer annealing at 49.1$56^{\circ} \mathrm{C}$ for $45 \mathrm{~s}$, and primer elongation at $72^{\circ} \mathrm{C}$ for $2 \mathrm{~min}$, with a final extension stage at $72{ }^{\circ} \mathrm{C}$ for $10 \mathrm{~min}$. 
Table 1 Information of 48 Iranian Ae. triuncialis accessions investigated in the present study

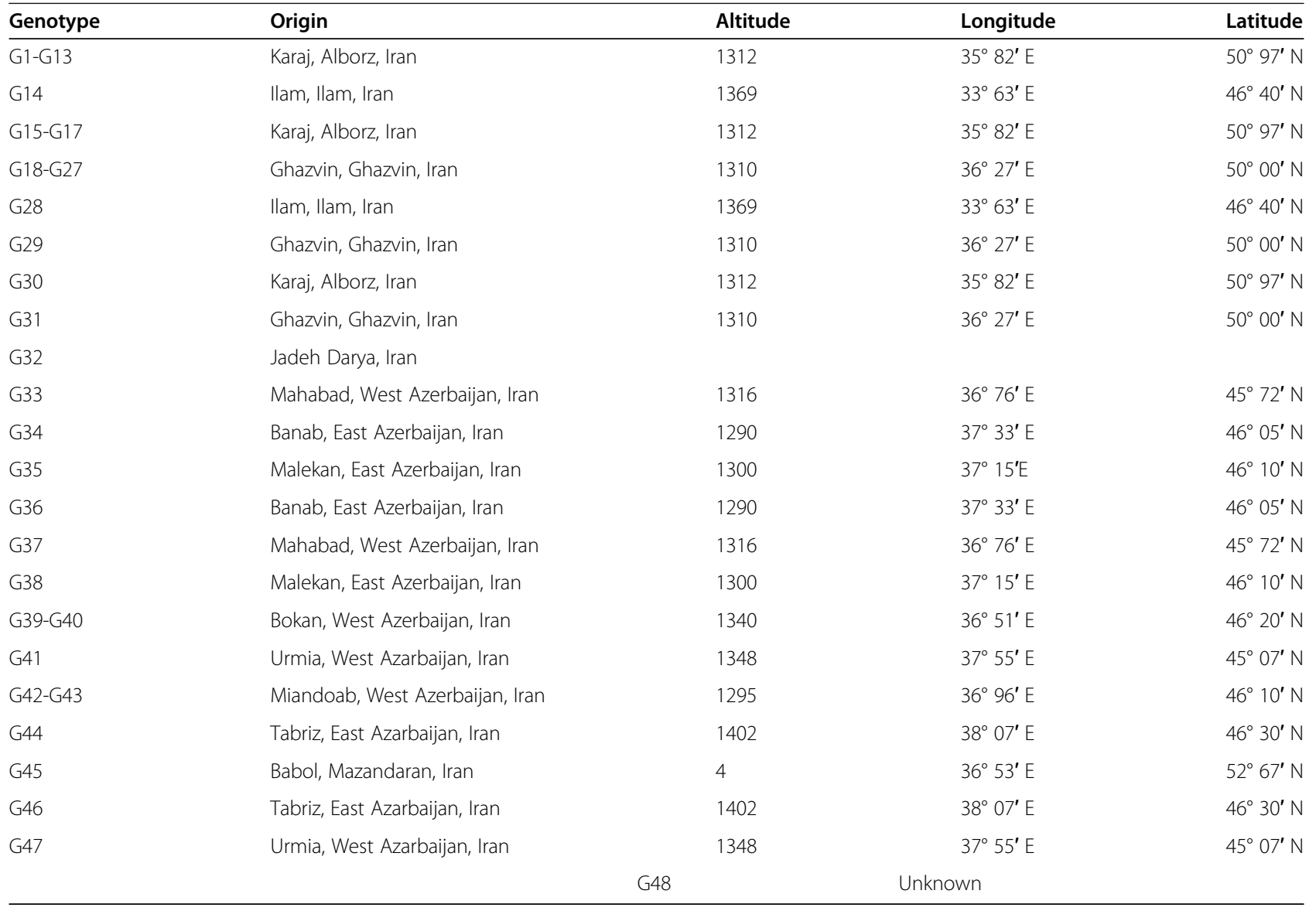

Table 2 N, NP, Rp, PIC, and MI indexes in Ae. triuncialis genotypes produced by ISSR primers

\begin{tabular}{llllllll}
\hline Primer & Primer sequence & N & NP & Rp & PIC & MI \\
\hline 1 & IS1 & DBDACACACACACACACA & 6 & 6 & 1.79 & 0.25 & 1.50 \\
2 & IS3 & GACAGACAGACAGACA & 11 & 11 & 5.75 & 0.34 & 3.74 \\
3 & IS4 & AGAGAGAGAGAGAGAGYT & 14 & 14 & 4.33 & 0.23 & 3.22 \\
4 & IS5 & ACACACACACACACACC & 7 & 7 & 4.38 & 0.39 & 2.73 \\
5 & IS6 & GAGAGAGAGAGAGAGARC & 13 & 12 & 4.00 & 0.24 & 2.65 \\
6 & IS7 & CTCTCTCTCTCTCTCTG & 12 & 12 & 6.25 & 0.36 & 4.32 \\
7 & IS9 & CACACACACACACACAG & 12 & 11 & 3.04 & 0.23 & 2.31 \\
8 & IS11 & ACACACACACACACACYA & 10 & 10 & 2.71 & 0.22 & 2.2 \\
9 & IS12 & GTGTGTGTGGTGTGTYG & 7 & 7 & 2.71 & 0.29 & 2.03 \\
10 & IS13 & GAGAGAGAGAGAGAGAYC & 7 & 6 & 2.67 & 0.30 & 1.54 \\
11 & IS14 & AGAGAGAGAGAGAGAGT & 10 & 9 & 2.17 & 0.20 & 1.62 \\
12 & IS15 & ACACACACACACACACYG & 8 & 7 & 2.67 & 0.25 & 1.53 \\
13 & IS23 & CTCTCTCTCTCTCTCTRC & 11 & 9 & 5.00 & 0.37 & 2.72 \\
14 & IS25 & CACACACACACACACARG & 13 & 11 & 4.58 & 0.29 & 2.67 \\
15 & IS27 & TGTGTGTGTGGTGTGRC & 10 & 9 & 6.21 & 0.41 & 3.32 \\
16 & IS28 & TCTCTCTCTCTCTCTCG & 11 & 11 & 7.96 & 0.42 & 4.62 \\
& & Mean & & 9.5 & 4.14 & 0.30 & 2.67 \\
\hline
\end{tabular}

$N$ total number, $N P$ number of polymorphic bands, $R p$ resolving power, $P I C$ polymorphic information content, $M I$ marker index

\section{Visualization of amplified fragments and data analysis}

The PCR products were laid out on $1.5 \%$ agarose gels using electrophoresis. They were post-stained with SafeView-IITM. Bands were visualized under UV light by gel documentation.

PCR products were visually scored for their presence (1) or absence (0) based on their gel patterns. Statistical analysis for generated data matrices was done by the DARwin computer software [28]. The preferential power of the primers was evaluated using three useful parameters, i.e., polymorphism information content (PIC), Rp, and MI. Accordingly, PIC was calculated according to the formula: $1-S p_{\mathrm{i}}^{2}$ as PIC $=1-S p_{\mathrm{i}}^{2}$ where $p_{\mathrm{i}}$ is the frequency of the $i$ th allele of the locus [29]. MI was calculated according to a formula described by Kumar et al. [30]. The distance coefficient matrix for the three marker data was calculated using the Jaccard distance index. To show the genetic relationships among the studied accessions, a dendrogram was constructed based on the unweighted pair group method with an arithmetic mean algorithm (UPGMA) using the DARwin5.0 software and NTYSYS 2.02 [31]. Using the GenAlEX 6.5 software, a principal coordinate analysis (PCoA) was performed in order to assess the distribution of the 
accessions. In addition, different genetic diversity indices such as the percentage of polymorphic loci (PPL), the observed $(\mathrm{Na})$ and effective number of alleles $(\mathrm{Ne})$, Nei's gene diversity $(\mathrm{H})$, and Shannon's information index (I) were measured by the POPGENE software, version 1.31 [32].

\section{Results}

\section{Molecular analysis of the markers}

One representative profile of each marker is shown in Fig. 1. All 16 ISSR primers produced reproducible polymorphic bands, with 152 amplified polymorphic bands generated across the accessions (Table 2). The number of polymorphic bands varied from 6 (IS- 8 and IS-13 primers) to 14 bands (IS-4 primer), with an average of 9.5 bands per primer pair and $93.98 \%$ polymorphism rate. Also, the PIC ranged from 0.2 (IS-14 primer) to 0.42 (IS-28 primer) with an average of 0.3 per primer pair. The lowest and highest values of MI were observed in IS-1 (1.5) and IS-18 (4.62) primers, respectively. The $\mathrm{Rp}$ of the primers varied from 1.79 (IS-1 primer) to 7.96 (IS-28 primer), with a mean value of 4.14 .

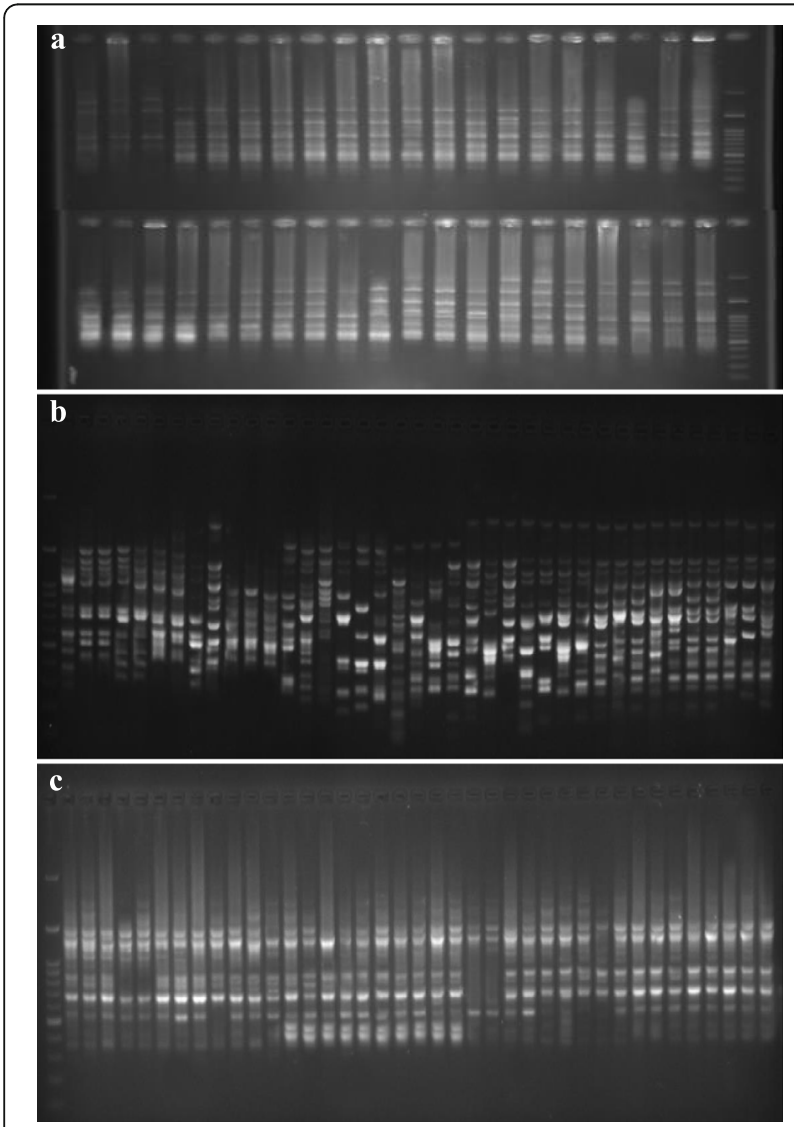

Fig. 1 Electrophoretic profile of PCR products using IS13 (a), SC9 (b), and P10 (c) primers for 40 Ae. triuncialis genotypes
The SCoT primers generated 162 amplified fragments. Most of them were polymorphic (90.74\%). The number of amplified fragments varied from 7 (SC-5, 7, 14) to 14 $(\mathrm{SC}-2,9)$ with an average of 10.5 fragments per primer pair. Furthermore, the average values of PIC, MI, and RP were $0.26,2.52$, and 4 , respectively (Table 3 ). The SC-14 and $\mathrm{SC}-3$ primers revealed the maximum $(0.42)$ and minimum (0.14) of PIC, respectively. In addition, the lowest and the highest MI values were 1.16 and 4.42, being observed in SC-1 and SC-24 primers, respectively.

The CBDP primers generated 101 bands, $95.05 \%$ of which were polymorphic. The number of amplified fragments ranged from $5(\mathrm{P}-5,7,8,15)$ to $14(\mathrm{P}-14)$ with an average of 7.38 fragments per primer pair (Table 4). Moreover, the average values of PIC, MI, and Rp for CBDP primers were $0.34,2.32$, and 3.57 , respectively. Among different CBDP primers, P-14 primers showed maximum MI (5.04) and $\mathrm{Rp}$ (7.21) indices, whereas the minimum values of PIC (0.21), MI (1.28), and Rp (1.88) indices were observed in the $\mathrm{P}-10$ primer.

\section{Cluster analysis}

Cluster analysis involved using the UPGMA method based on Jaccard's distance coefficient. The accessions were classified into six groups based on the ISSR clustering pattern (Fig. 2a). The minimum genetic distance (0.16) was observed between G19 and G20 accessions, belonging to Qazvin Province, whereas a maximum genetic similarity of 0.78 was observed between G43 and G29, and also between G30 and G2 accessions.

Table 3 N, NP, Rp, PIC, and Ml indexes in Ae. triuncialis genotypes produced by SCOT primer

\begin{tabular}{|c|c|c|c|c|c|c|c|}
\hline \multicolumn{2}{|c|}{ Primer } & \multirow{2}{*}{$\begin{array}{l}\text { Primer sequence } \\
\text { CAACAATGGCTACCACCC }\end{array}$} & \multirow{2}{*}{$\frac{\mathbf{N}}{14}$} & \multirow{2}{*}{$\frac{N P}{14}$} & \multirow{2}{*}{$\frac{\mathrm{Rp}}{5.83}$} & \multirow{2}{*}{$\frac{\text { PIC }}{0.25}$} & \multirow{2}{*}{$\frac{\text { MI }}{3.50}$} \\
\hline 1 & $\mathrm{SC2}$ & & & & & & \\
\hline & & CAACAATGGCTACCACCG & 12 & 11 & 1.83 & 0.14 & \\
\hline & SC4 & & 12 & 12 & & 0.29 & 3.48 \\
\hline & SC5 & CCACGA & 7 & 7 & 2.62 & 0.26 & 1.82 \\
\hline & SC7 & & 9 & 7 & & & 1.41 \\
\hline & SC8 & & 15 & 12 & & 0.18 & 1.72 \\
\hline & SC9 & CCAGCA & 14 & 14 & 6.00 & 0.29 & 4.06 \\
\hline & SC11 & AAGC & 11 & 8 & & 0.20 & 1.16 \\
\hline & SC12 & ACGA & 11 & 11 & 54 & 0.32 & 3.52 \\
\hline 10 & SC14 & ACGACATGGCGACCACCG & 8 & 7 & & 0.42 & 2.57 \\
\hline 11 & SC15 & TGGCGACCGCGA & 12 & 12 & 4.08 & 0.24 & 2.88 \\
\hline 12 & SC21 & CACCATGGCTACCACCAT & 12 & 9 & 2.62 & 0.23 & 1.55 \\
\hline 13 & SC24 & CCACCGCCA & 13 & 13 & 6.93 & 0.34 & 4.42 \\
\hline \multirow[t]{2}{*}{14} & SC26 & ACAATGGCTACCACCATC & 12 & 10 & 3.12 & 0.22 & 1.83 \\
\hline & & Mean & & 10.5 & 4.00 & 0.26 & 2.52 \\
\hline
\end{tabular}

$N$ total number, $N P$ number of polymorphic bands, $R p$ resolving power, $P I C$ polymorphic information content, $M I$ marker index 
Table 4 N, NP, Rp, PIC, and MI indexes in Ae. triuncialis genotypes produced by CBDP primer

\begin{tabular}{llllllll}
\hline \multicolumn{2}{l}{ Primer } & Primer sequence & N & NP & Rp & PIC & MI \\
\hline 1 & P1 & TGAGCACGATCCAATAGC & 8 & 8 & 5.17 & 0.42 & 3.36 \\
2 & P2 & TGAGCACGATCCAATAAT & 10 & 9 & 3.50 & 0.26 & 2.10 \\
3 & P3 & TGAGCACGATCCAATACC & 8 & 7 & 3.33 & 0.35 & 2.14 \\
4 & P4 & TGAGCACGATCCAATAAG & 6 & 6 & 3.88 & 0.39 & 2.34 \\
5 & P5 & TGAGCACGATCCAATCTA & 5 & 5 & 2.42 & 0.33 & 1.65 \\
6 & P7 & TGAGCACGATCCAATCGA & 6 & 5 & 2.88 & 0.39 & 1.62 \\
7 & P8 & TGAGCACGATCCAATCGG & 5 & 5 & 3.21 & 0.41 & 2.05 \\
8 & P9 & TGAGCACGATCCAATGAT & 7 & 7 & 3.13 & 0.32 & 2.24 \\
9 & P10 & TGAGCACGATCCAATGTT & 8 & 7 & 1.88 & 0.21 & 1.28 \\
10 & P12 & TGAGCACGATCCAATATA & 9 & 9 & 3.33 & 0.25 & 2.25 \\
11 & P13 & TGAGCACGATCCAATGAG & 9 & 9 & 2.63 & 0.25 & 2.25 \\
12 & P14 & TGAGCACGATCCAATGCG & 14 & 14 & 7.21 & 0.36 & 5.04 \\
13 & P15 & TGAGCACGATCCAATGA & 6 & 5 & 3.75 & 0.46 & 1.91 \\
& & MEAN & & 7.38 & 3.57 & 0.34 & 2.32 \\
\hline
\end{tabular}

$N$ total number, $N P$ number of polymorphic bands, $R p$ resolving power, $P I C$ polymorphic information content, $M I$ marker index

The accessions were grouped into five clusters using SCoT data. The maximum genetic distance $(0.75)$ was observed between G39 and G6, whereas the minimum (0.31) was observed between G36 and G35 accessions. Based on the SCoT marker, the accessions in each group showed a considerable amount of diversity, owing to their geographical distribution (Fig. 2b). The dendrogram generated by CBDP data showed the presence of five clusters (Fig. 2c). The genetic distances ranged from 0.03 (between G12 and G13) to 0.97 (between G16 and G47), with an average of 0.54. According to the results, most of the Alborz accessions were clustered into a group based on the dendrogram generated by each marker, including ISSR, SCoT, and CBDP. In addition, Qazvin accessions formed another group, although some of the accessions collected from this Province were categorized in other groups as well. Similar to the Alborz and Qazvin accessions, the accessions that were collected from East and West Azerbaijan Provinces were allocated to one group. These results were also observed when combining the data of the three markers (Fig. 2d). To determine the genetic relationships among and within the collected populations, PCoA was used. According to the results of the above analysis, the first two PCoA axes in ISSR, SCoT, and CBDP markers confirmed $77.28,78.03$, and $76.67 \%$ of the total variation among the studied accessions, respectively. The bi-plots confirmed the results of cluster analyses for the three markers (Fig. 3). In both analyses, the patterns of variation correspond to geographical distribution of the $A e$. triuncialis accessions.

\section{Genetic variation revealed by the markers}

According to ISSR data, the highest number of alleles (1.770) and Shannon index (0.393) were observed in accessions collected from the northwest of the country, whereas the lowest of these indices were in accessions collected from Qazvin Province. Also, the highest PPL (86.18\%) belonged to northwestern populations (Table 5).

Based on the SCoT markers, the highest $(77.55 \%)$ and lowest (63.27\%) PPL were attributed to accessions of the northwest and Qazvin Province, respectively. The highest and lowest values of Shannon information index were observed in populations of Alborz and Qazvin Provinces, respectively. For CBDP markers, the Na value varied from 1.45 to 1.79 (in Qazvin and northwest populations, respectively). The maximum $(0.31)$ and minimum (0.23) Shannon index were observed in Alborz and Qazvin populations, respectively. The highest (89.58\%) and lowest $(65.63 \%)$ of PPL were found in the northwest and Qazvin populations, respectively. The average of PPL (79.51\%) indicated a proper distribution and usefulness of the markers.

\section{Discussion}

Studying genetic diversity among wild wheat species is important in breeding programs that involve interspecific crossings or targeted gene transfer in efforts to sustain and improve plant traits [33]. Landraces and wild crops can have unique traits and wide ranges of distribution in the plant flora in different geographical areas [34]. Therefore, assessments of genetic diversity among and within the wild relatives of bread wheat can be valuable steps before their evaluation in terms of resistance to biotic and abiotic stress. So far, few studies have been carried out on genetic diversity within populations of the Aegilops species, with a focus on valuable genes that express tolerance to different types of stress such as drought [35], heat [36], salinity [36], pests, and diseases [5]. In this study, three marker systems were used for investigating the genetic diversity among Iranian Ae. trianiensis accessions. To the best of our knowledge, this is the first report on genetic diversity among Ae. triuncialis accessions using two new markers, i.e., SCoT and CBDP, along with ISSR markers. In the present study, a high level of polymorphism was observed among the accessions in which the polymorphism percentages for SCoT, CBDP, and ISSR markers were 90.57, 94.74, and 93.97, respectively. The SCoT and CBDP markers were regarded as suitable for studying genetic diversity in wheat [37]. The ISSR primers can target microsatellites that are abundant throughout the plant genome. Thus, the markers have proven to be more reproducible than other markers such as RAPD [38]. However, the results of the present study showed that the CBDP markers, despite its ability to produce fewer bands, had the highest percentage of polymorphism in comparison with other 


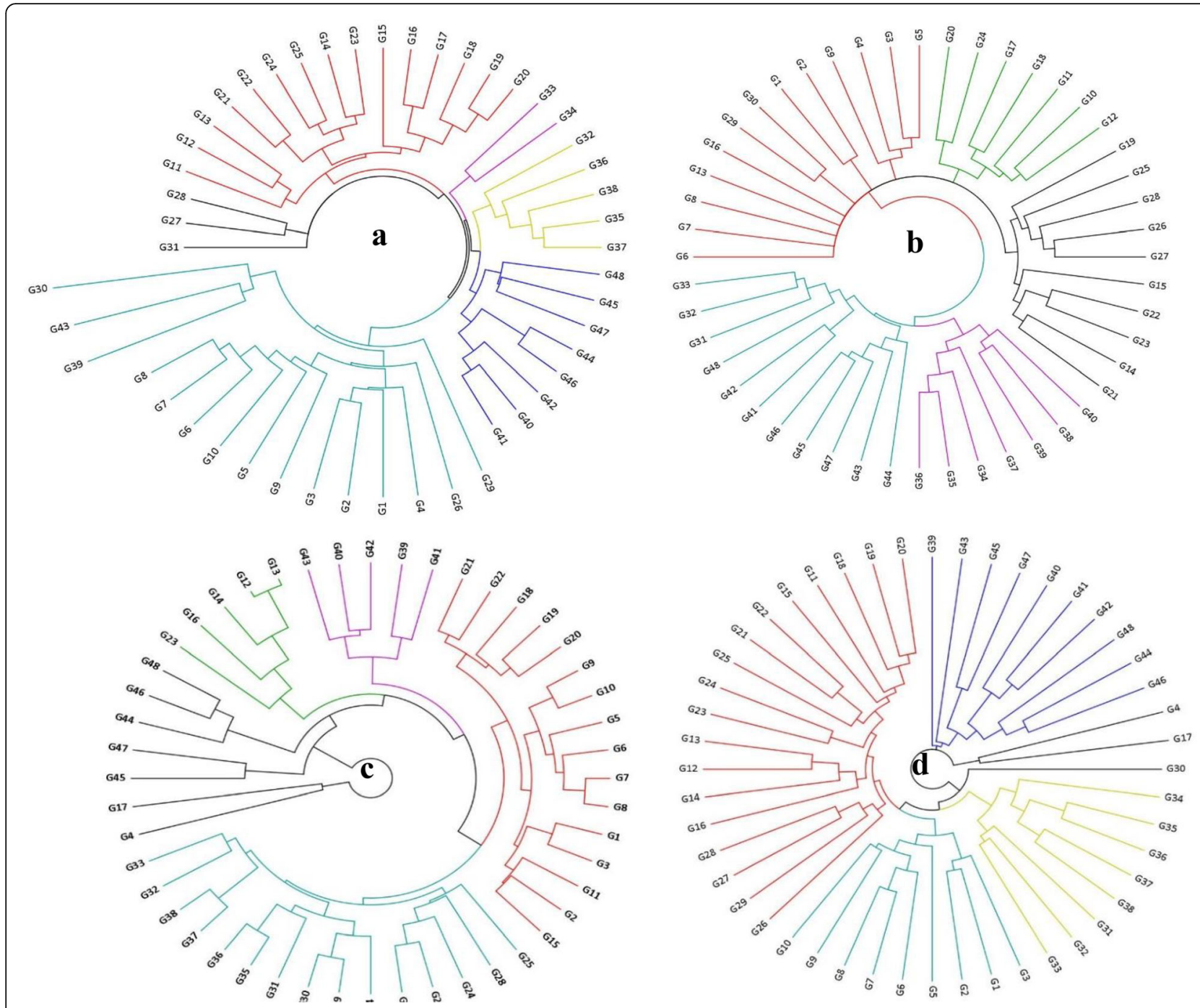

Fig. 2 Dendrogram of 48 Ae. triuncialis accessions using UPGMA method based on ISSR (a), SCOT (b), CBDP (c), and all the three markers (d) data

markers (94.74\%). The average PIC value for the CBDP primers was also higher than the other marker systems. Botstein et al. [39] stated that primers with a PIC value ranging from 0.25 to 0.50 contain useful information for genetic diversity studies. In agreement with our findings, Heikrujam et al. [14] reported that in terms of the PIC value, CBDP markers are more effective than SCoT markers when studying genetic diversity among male and female jojoba genotypes. Furthermore, other informative indices including Rp and MI showed a great approval of the discriminating power of these three markers. The higher values of MI and Rp in SCoT-24, SCoT-12, SCoT9, and SCoT-4 primers indicated a better resolution and higher potency of these primers, as compared to other SCoT primers, which could be useful in future studies in Aegilops species. Etminan et al. [40] used ISSR and SCoT marker systems to detect genetic diversity in durum wheat genotypes. The authors indicated that Rp and MI could be the most important indices in determining marker efficiency, while the ISSR had a higher resolution than SCoT markers, as this was consistent with our findings. Also, the results of the present study confirmed the usefulness of these markers for identifying the genetic diversity of wheat and of its wild relative genotypes [41-43].

According to the Shannon index, the Alborz population had a higher variation than the other populations, which was confirmed by heterozygosity values.

All three marker systems showed the highest PPL in the northwestern genotypes, indicating a high allelic diversity and the heterogeneity of these genotypes. Our results confirmed that the main center for the diversity of the genus Aegilops in Iran was most probably located in the north and northwest of the country [44].

The dendrograms obtained from the three sets of data were roughly in line with the geographical origin of the samples. Reddy et al. [45] claimed that the accurate 


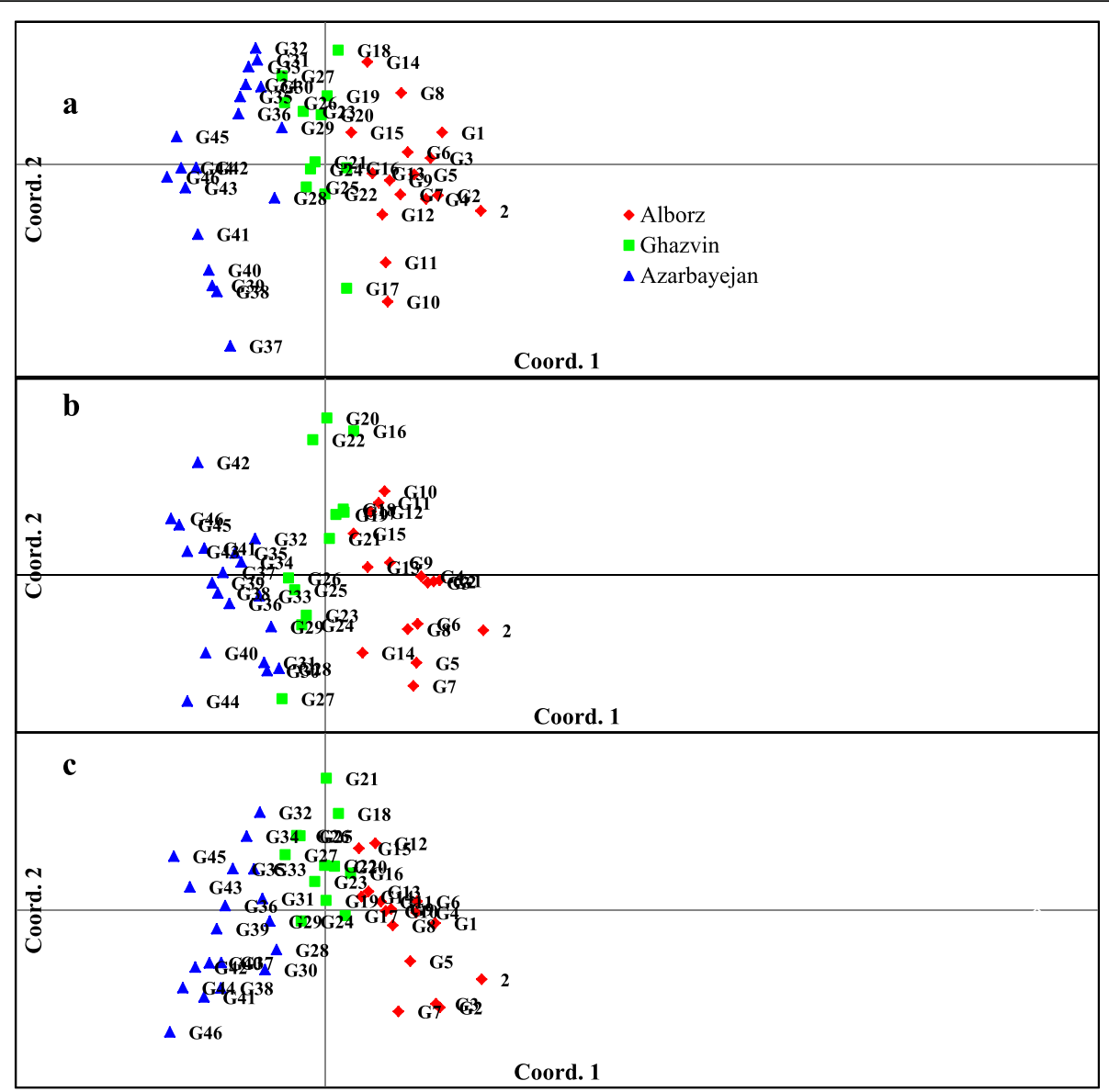

Fig. 3 Bi-plots derived from the PCoA of 48 Ae. triuncialis accessions using ISSR (a), SCOT (b), and CBDP (c) data (1-40 are G1-G48 accessions)

selection of ISSR primers could reveal an appropriate estimation of genetic variation to identify and classify data.

Baranduzi et al. [46] studied genetic diversity of Aegilops species using ISSR primers. Their samples were separated into six distinct clusters, which did not have any relationship with the geographical distribution pattern. In the present study, this relationship was based on ISSR and SCoT data and happened to be greater than CBDP data. The polymorphism in CBDP is due to the variation of the CAAT box in eukaryotic genomes [47]. Therefore, it seems that the accessions in distant geographic regions may have the same gene pool. Etminan et al. [48] reported that the genetic diversity among Iranian durum wheat germplasms was not in accordance with the geographical distribution, and that all accessions might be grouped based on their genomic structure. Fathi et al. [49] analyzed the genetic variation among Ae. triunsialis accessions by 5 IRAP markers. The authors observed a low level of relationship between genetic divergence and geographical origins of the samples. The three markers in the present study, i.e., ISSR, SCoT, and CBDP, were more appropriate for studying genetic diversity among and within Aegilops species, as compared to the IRAP markers. In the present study, different results and

Table 5 Genetic variation features estimated using ISSR, SCOT, and CBDP markers in Ae. triuncialis populations

\begin{tabular}{|c|c|c|c|c|c|c|c|c|c|}
\hline \multirow[t]{2}{*}{ Parameters } & \multicolumn{3}{|l|}{ ISSR } & \multicolumn{3}{|l|}{ SCoT } & \multicolumn{3}{|l|}{ CBDP } \\
\hline & Northwest & Ghazvin & Alborz & Northwest & Ghazvin & Alborz & Northwest & Ghazvin & Alborz \\
\hline PPL (\%) & 86.18 & 70.39 & 80.26 & 77.55 & 63.27 & 70.07 & 89.58 & 65.63 & 83.33 \\
\hline $\mathrm{Na}$ & $1.77 \pm 0.03$ & $1.52 \pm 0.03$ & $1.65 \pm 0.03$ & $1.59 \pm 0.04$ & $1.37 \pm 0.04$ & $1.46 \pm 0.04$ & $1.66 \pm 0.04$ & $1.45 \pm 0.04$ & $1.79 \pm 0.04$ \\
\hline NA & $1.43 \pm 0.01$ & $1.36 \pm 0.01$ & $1.44 \pm 0.01$ & $1.29 \pm 0.02$ & $1.29 \pm 0.02$ & $1.36 \pm 0.02$ & $1.55 \pm 0.02$ & $1.39 \pm 0.02$ & $1.51 \pm 0.02$ \\
\hline I & $0.39 \pm 0.01$ & $0.32 \pm 0.01$ & $0.39 \pm 0.01$ & $0.29 \pm 0.012$ & $0.28 \pm 0.012$ & $0.33 \pm 0.012$ & $0.45 \pm 0.01$ & $0.35 \pm 0.01$ & $0.44 \pm 0.01$ \\
\hline $\mathrm{He}$ & $0.25 \pm 0.01$ & $0.21 \pm 0.01$ & $0.25 \pm 0.01$ & $0.18 \pm 0.01$ & $0.18 \pm 0.01$ & $0.22 \pm 0.01$ & $0.31 \pm 0.01$ & $0.23 \pm 0.01$ & $0.26 \pm 0.01$ \\
\hline
\end{tabular}

PPL percentage of polymorphic loci, $\mathrm{Na}$ observed no. of alleles, Ne effective no. of alleles, I Shannon index, He heterozygosity 
clustering were obtained by the three markers, due to the ability of each marker to reproduce different regions of the genome [16]. Therefore, these three markers provide more detail and diverse information about genetic diversity among and within the Iranian Ae. triuncialis accessions [50]. Mismatching results among the dendrograms being generated by different markers in different plants were indicated, such as in snake melon [51], sponge gourd [52], and bamboos [53]. The results of PCoA plots for the three marker systems confirmed the results of cluster analyses. The three bi-plots separated the samples according to their geographical locations. These results again demonstrated the ability of the three marker systems to identify the genetic diversity among the Iranian Ae. triuncialis accessions.

\section{Conclusion}

The results of the present study revealed a high level of polymorphism in the Iranian Ae. triuncialis accessions by the three marker systems. Also, the results confirmed the efficiency of ISSR, SCoT, and CBDP markers in estimating the genetic diversity among the accessions. The three marker systems showed a comprehensive pattern of the genetic diversity among the Iranian Ae. triuncialis accessions, which could provide a future insight into wheat breeding programs.

\section{Abbreviations}

CBDP: CAAT box-derived polymorphism; CWRs: Crop wild relatives; H: Nei's gene diversity; I: Shannon index; ISSR: Inter-simple sequence repeats; MI: Marker index; PCoA: Principal coordinate analysis; PIC: Polymorphic information content; PPL: Percentage of polymorphic loci; Rp: Resolving power; SCOT: Start codon targeted; UPGMA: Unweighted pair group method with arithmetic mean algorithm.

\section{Acknowledgements}

Not applicable

\section{Authors' contributions}

RA and AE conceived the research idea and designed the experiments. LK, $A E, R A$, and MK performed the experiments and analyzed the data. LK wrote the manuscript. The authors read and approved the final manuscript.

\section{Funding}

Not applicable

\section{Availability of data and materials}

All data generated or analyzed during this study are included in this published article.

\section{Ethics approval and consent to participate}

This article does not contain any studies with human participants or animals performed.

\section{Consent for publication}

Not applicable

\section{Competing interests}

The authors declare that they have no competing interests.

\section{Author details}

'Department of Biotechnology and Plant Breeding, Islamic Azad University Science and Research Branch, Tehran, Iran. ${ }^{2}$ Department of Plant Breeding and Biotechnology, Kermanshah Branch, Islamic Azad University, Kermanshah, Iran

Received: 25 September 2020 Accepted: 21 December 2020

Published online: 11 January 2021

\section{References}

1. Lane A, Jarvis A (2007) Changes in climate will modify the geography of crop suitability: agricultural biodiversity can help with adaptation. SAT E J 4 : 1-12. https://doi.org/10.3914/ICRISAT.0094

2. Maxted N (2008) Crop wild relative conservation and use. CABI

3. Ronald P (2011) Plant genetics, sustainable agriculture and global food security. Genetics 188:11-20. https://doi.org/10.1534/genetics.111.128553

4. Vasil IK (2007) Molecular genetic improvement of cereals: transgenic wheat (Triticum aestivum L.). Plant Cell Rep 26:1133-1154. https://doi.org/10.1007/ s00299-007-0338-3

5. Kishii M (2019) An update of recent use of Aegilops species in wheat breeding. Front Plant Sci 10. https://doi.org/10.3389/fpls.2019.00585

6. Kilian B, Mammen K, Millet E, Sharma R, Graner A, Salamini F et al (2011) Aegilops, wild crop relatives, genomic and breeding resources. Cereal (Ed Kole, C):1-76

7. Arzani A, Khalughi M-R, Shiran B, Kharazian N (2018) Evaluation of diversity in wild relatives of wheat (key note). Czech J Genet Plant Breed 41:112-117. https://doi.org/10.17221/6149-cjgpb

8. Sanjari S, Shirzadian-Khorramabad R, Shobbar ZS, Shahbazi M (2019) Systematic analysis of NAC transcription factors' gene family and identification of post-flowering drought stress responsive members in sorghum. Plant Cell Rep 38:361-376. https://doi.org/10.1007/s00299-01902371-8

9. Sheikh-Mohamadi MH, Etemadi N, Nikbakht A, Farajpour M, Arab M, Majidi MM (2017) Screening and selection of twenty iranian wheatgrass genotypes for tolerance to salinity stress during seed germination and seedling growth stage. HortScience 52:1125-1134. https://doi.org/10.21273/HORTSCI12103-17

10. Peng JH, Sun D, Nevo E (2011) Domestication evolution, genetics and genomics in wheat. Mol Breed 28:281-301. https://doi.org/10.1007/s11032011-9608-4

11. Colmer TD, Flowers TJ, Munns R (2006) Use of wild relatives to improve salt tolerance in wheat. J Exp Bot 570xford Academic:1059-1078. https://doi. org/10.1093/jxb/erj124

12. Collins FS, Green ED, Guttmacher AE, Guyer MS (2003) A vision for the future of genomics research. Nature 422:835-847. https://doi.org/10.1038/ nature01626

13. Astarini IA, Plummer JA, Lancaster RA, Yan G (2004) Fingerprinting of cauliflower cultivars using RAPD markers. Aust J Agr Res 55:117-124. https:// doi.org/10.1071/AR03012

14. Heikrujam M, Kumar J, Agrawal V (2015) Genetic diversity analysis among male and female jojoba genotypes employing gene targeted molecular markers, start codon targeted (SCOT) polymorphism and CAAT box-derived polymorphism (CBDP) markers. Meta Gene 5:90-97. https://doi.org/10.1016/ J.MGENE.2015.06.001

15. Collard BCY, Mackill DJ (2009) Start codon targeted (SCOT) polymorphism: a simple, novel DNA marker technique for generating gene-targeted markers in plants. Plant Mol Biol Rep 27:86-93. https://doi.org/10.1007/s11105-0080060-5

16. Gajera BB, Kumar N, Singh AS, Punvar BS, Ravikiran R, Subhash N et al (2010) Assessment of genetic diversity in castor (Ricinus communis L.) using RAPD and ISSR markers. Ind Crop Prod 32:491-498. https://doi.org/10.1016/j. indcrop.2010.06.021

17. Amirmoradi B, Talebi R, Karami E (2012) Comparison of genetic variation and differentiation among annual Cicer species using start codon targeted (SCOT) polymorphism, DAMD-PCR, and ISSR markers. Plant Syst Evol 298: 1679-1688. https://doi.org/10.1007/s00606-012-0669-6

18. Hamidi $H$, Talebi $R$, Keshavarzi $F$ (2014) Comparative efficiency of functional gene-based markers, start codon targeted polymorphism (SCOT) and conserved DNA-derived polymorphism (CDDP) with ISSR markers for diagnostic fingerprinting in wheat (Triticum aestivum L.). Cereal Res Commun 42:558-567. https://doi.org/10.1556/CRC.2014.0010

19. Tabasi M, Sheidai M, Hassani D, Koohdar F (2020) DNA fingerprinting and genetic diversity analysis with SCOT markers of Persian walnut populations (Juglans regia L.) in Iran. Genet Resour Crop Evol 67:1437-1447. https://doi. org/10.1007/s10722-020-00914-7 
20. Farajpour M, Ebrahimi M, Amiri R, Noori SAS, Sanjari S, Golzari R (2011) Study of genetic variation in yarrow using inter-simple sequence repeat (ISSR) and random amplified polymorphic DNA (RAPD) markers. Afr J Biotechnol 10:73-86

21. Ebrahimi M, Farajpour M, Rahimmalek M (2012) Inter- and intra-specific genetic diversity of Iranian yarrow species Achillea santolina and Achillea tenuifolia based on ISSR and RAPD markers. Genet Mol Res 11

22. Farajpour M, Ebrahimi M, Amiri R, Golzari R, Sanjari S (2012) Assessment of genetic diversity in Achillea millefolium accessions from Iran using ISSR marker. Biochem Syst Ecol 43:73-79. https:/doi.org/10.1016/j.bse.2012.02.017

23. Maleki M, Shojaeiyan A, Monfared SR (2018) Population structure, morphological and genetic diversity within and among melon (Cucumis melo L.) landraces in Iran. J Genet Eng Biotechnol 16:599-606

24. Baruah J, Pandey SK, Begum T, Sarma N, Paw M, Lal M (2019) Molecular diversity assessed amongst high dry rhizome recovery ginger germplasm (Zingiber officinale roscoe) from NE-India using RAPD and ISSR markers. Ind Crop Prod 129:463-471. https://doi.org/10.1016/j.indcrop.2018.12.037

25. Saxena A (2014) Vol TR-RJ of B, 2020 U. assessment of genetic diversity in cowpea (Vigna unguiculata L. Walp.) germplasm. Bull Inst Trop Agric Kyushu Univ 37:57-63. https://doi.org/10.11189/bita.37.57

26. Hargreaves AJ, Farmani R, Ward S, Butler D (2019) Modelling the future impacts of urban spatial planning on the viability of alternative water supply. Water Res 162:200-213. https://doi.org/10.1016/j.watres.2019.06.029

27. Liu W, Zhou Y, Liao H, Zhao Y, Song Z (2011) A rapid DNA isolation procedure for small quantities of fresh leaf tissue. Am J Bot 98:202-222. https://doi.org/10.1016/j.bse.2009.07.003

28. Perrier X, Jaccqemoud-Collet J (2014) Dissimilarity analysis and representation for windows DARWIN, p 115

29. Anderson JA, Churchill GA, Autrique JE, Tanksley SD, Sorrells ME (1993) Optimizing parental selection for genetic linkage maps. Genome 36: 181-186. https://doi.org/10.1139/g93-024

30. Kumar M, Mishra GP, Singh R, Kumar J, Naik PK, Singh SB (2009) Correspondence of ISSR and RAPD markers for comparative analysis of genetic diversity among different apricot genotypes from cold arid deserts of trans-Himalayas. Physiol Mol Biol Plants 15:225-236. https://doi.org/10. 1007/s12298-009-0026-6

31. Rohlf FJ (2009) NTSYSpc: numerical taxonomy and multivariate analysis system ver. 2.2. https://doi.org/10.2307/2684761

32. Yeh FC, Yang R, Boyle T (1997) POPGENE version 1.30: Microsoft windowbased freeware for population genetic analysis http://www.ualberta.ca/ fyeh/index.htm

33. Wolt JD (2019) Current risk assessment approaches for environmental and food and feed safety assessment. Transgenic Res 28:111-117. https://doi. org/10.1007/s11248-019-00140-7

34. Feuillet $C$, Langridge $P$, Waugh $R$ (2008) Cereal breeding takes a walk on the wild side. Trends Genet 24:24-32. https://doi.org/10.1016/j.tig.2007.11.001

35. Faroog S, Azam FE (2001) Co-existence of salt and drought tolerance in Triticeae. Hereditas 135:205-210. https://doi.org/10.1111/j.1601-5223.2001. 00205.x

36. Waines J (1994) High temperature stress in wild wheats and spring wheats Funct Plant Biol 21:705. https://doi.org/10.1071/pp9940705

37. Pour-Aboughadareh A, Ahmadi J, Mehrabi AA, Etminan A, Moghaddam M (2018) Insight into the genetic variability analysis and relationships among some Aegilops and Triticum species, as genome progenitors of bread wheat, using SCoT markers. Plant Biosyst 152:694-703. https://doi.org/10. 1080/11263504.2017.1320311

38. Debnath SC (2009) Development of ISSR markers for genetic diversity studies in Vaccinium angustifolium. Nord J Bot 27:141-148. https://doi.org/ 10.1111/j.1756-1051.2009.00402.x

39. Botstein D, White RL, Skolnick M, Davis RW (1980) Construction of a genetic linkage map in man using restriction fragment length polymorphisms. Am J Hum Genet 32:314

40. Etminan A, Pour-Aboughadareh A, Mohammadi R, Ahmadi-Rad A, Noori A, Mahdavian Z et al (2016) Applicability of start codon targeted (SCOT) and inter-simple sequence repeat (ISSR) markers for genetic diversity analysis in durum wheat genotypes. Biotechnol Biotechnol Equip 30:1075-1081. https://doi.org/10.1080/13102818.2016.1228478

41. Kong J, Xie YF, Guo YH, Cheng YL, Qian H, Yao WR (2016) Biocontrol of postharvest fungal decay of tomatoes with a combination of thymol and salicylic acid screening from 11 natural agents. LWT- Food Sci Technol 72: 215-222. https://doi.org/10.1016/j.lwt.2016.04.020
42. Gholamian F, Etminan A, Changizi M, Khaghani S, Gomarian M (2019) Assessment of genetic diversity in Triticum urartu Thumanjan ex Gandilyan accessions using start codon targeted polymorphism (SCOT) and CAAT-box derived polymorphism (CBDP) markers. Biotechnol Biotechnol Equip 33: 1653-1662. https://doi.org/10.1080/13102818.2019.1691466

43. Heidari P, Etminan A, Azizinezhad R, Khosroshahli M (2017) Genomic variation studies in durum wheat (Triticum turgidum ssp. durum) using CBDP, SCOT and ISSR markers. Indian J Genet Plant Breed 77:379-386. https://doi.org/10.5958/0975-6906.2017.00051.7

44. Moradkhani H, Mehrabi AA, Etminan A, Pour-Aboughadareh A (2016) Molecular diversity and phylogeny of Triticum-Aegilops species possessing D genome revealed by SSR and ISSR markers. Plant Breed Seed Sci 71:8195. https://doi.org/10.1515/plass-2015-0024

45. Reddy MP, Sarla N, Siddiq EA (2002) Inter simple sequence repeat (ISSR) polymorphism and its application in plant breeding. Euphytica 128:9-17

46. Baranduzi AJ, Soflian O, Zakaria RA, Asghari A, Shokrpour M (2013) Assessment of genetic diversity in Aegilops species in north-west of Iran using ISSR marker. Yüzüncü Yıl Üniversitesi Tarım Bilim Derg 23:66-75

47. Boopathi NM (2020) Genotyping of mapping populationGenet. Mapp. Marker Assist. Sel. Springer Singapore, Singapore, pp 107-178. https://doi. org/10.1007/978-981-15-2949-8_4

48. Etminan A, Pour-Aboughadareh A, Mohammadi R, Ahmadi-Rad A, Moradi Z, Mahdavian Z et al (2017) Evaluation of genetic diversity in a mini core collection of Iranian durum wheat germplasms. J Anim Plant Sci 27:15821587

49. Fathi T, Sohani MM, Samizadeh H, Mehrabi AA (2014) International journal of biosciences. Vol. 4. In: International Network for Natural Sciences (INNS PUB)

50. Rao GK, Kapadia C, Patel NB, Desai KD, Narasimha Murthy PN (2020) Genetic diversity analysis of greater yam (Dioscorea alata L.) genotypes through RAPD and ISSR markers. Biocatal Agric. Biotechnol 23:101495. https://doi org/10.1016/j.bcab.2020.101495

51. Akash M, Awad N, Kasrawi M (2020) Genetic diversity among snake melon landraces (Cucumis Melo Var. Flexuosus) using molecular descriptors. Plant Biosyst 154:206-212. https://doi.org/10.1080/11263504.2019.1587536

52. Tyagi R, Sharma V, Sureja AK, Das Munshi A, Arya L, Saha D et al (2020) Genetic diversity and population structure detection in sponge gourd (Luffa cylindrica) using ISSR, SCOT and morphological markers. Physiol Mol Biol Plants 26:119-131. https://doi.org/10.1007/s12298-019-00723-y

53. Amom T, Tikendra L, Apana N, Goutam M, Sonia P, Koijam AS et al (2020) Efficiency of RAPD, ISSR, iPBS, SCOT and phytochemical markers in the genetic relationship study of five native and economical important bamboos of north-East India. Phytochemistry 174:112330. https://doi.org/10. 1016/.j.phytochem.2020.112330

\section{Publisher's Note}

Springer Nature remains neutral with regard to jurisdictional claims in published maps and institutional affiliations.

\section{Submit your manuscript to a SpringerOpen ${ }^{\circ}$ journal and benefit from:}

- Convenient online submission

- Rigorous peer review

- Open access: articles freely available online

- High visibility within the field

- Retaining the copyright to your article

Submit your next manuscript at $>$ springeropen.com 